\title{
The status of Rhoptrobothrium Shipley et Hornell, 1906 (Cestoda: Tetraphyllidea), with redescription of the type species, $R$. myliobatidis, and description of three new species from two species of Aetomylaeus (Myliobatiformes: Myliobatidae) from Malaysian Borneo
}

\author{
Kirsten Jensen $^{1}$ and Janine N. Caira ${ }^{2}$ \\ ${ }^{1}$ Department of Ecology and Evolutionary Biology and the Natural History Museum and Biodiversity Research Center, \\ University of Kansas, 1200 Sunnyside Ave., Lawrence, Kansas 66045, USA; \\ ${ }^{2}$ Department of Ecology and Evolutionary Biology, University of Connecticut, Unit 3043, 75 N. Eagleville Rd., Storrs, \\ Connecticut 06269-3043, USA
}

Key words: Cestoda, Tetraphyllidea, Rhoptrobothrium, Aetomylaeus, Thysanocephalinae, metascolex, Borneo

\begin{abstract}
As part of a metazoan parasite survey of elasmobranchs from Malaysian Borneo, specimens of Rhoptrobothrium Shipley et Hornell, 1906 were collected from the eagle rays Aetomylaeus maculatus (Gray) and Aetomylaeus niehofii (Bloch et Schneider). The type species is redescribed from its type host, and a neotype specimen is designated. In addition, three new species of Rhoptrobothrium are described: $R$. chongi sp. n., R. gambangi sp. n. and R. limae sp. n. Rhoptrobothrium myliobatidis conspicuously differs from the three new species in its lack of a secondary areola; $R$. limae is distinguished from $R$. chong $i$ and $R$. gambangi based on its greater total length; $R$. chongi possesses conspicuously stalked remi, while $R$. gambangi possesses short remi, often folded anteriorly. Rhoptrobothrium is somewhat unusual among tetraphyllideans in its possession of a "metascolex," a character it shares with other taxa in the Thysanocephalinae (i.e., Myzocephalus Shipley et Hornell, 1906, Myzophyllobothrium Shipley et Hornell, 1906 and Thysanocephalum Linton, 1889). The morphology of the "metascolex" of Rhoptrobothrium is investigated and new terminology is suggested to standardise the names given to structures constituting a metascolex. As a result, Rhoptrobothrium is considered to possess cephalic peduncle extensions, termed remi. In Rhoptrobothrium, each remus bears, at its distal end, a primary areola, and, in the case of the three new species, also a secondary areola proximal to the primary areola. Myzocephalus and Myzophyllobothrium are tentatively considered to possess remi; the configuration of the "metascolex" of Thysanocephalum, however, is not considered homologous to the condition in the other three genera currently placed in the Thysanocephalinae.
\end{abstract}

Shipley and Hornell (1906) erected Rhoptrobothrium Shipley et Hornell, 1906, with Rhoptrobothrium myliobatidis Shipley et Hornell, 1906 as its type species, based on a single scolex taken from "Myliobatis maculata" (= Aetomylaeus maculatus [Gray]), the mottled eagle ray, in Sri Lanka. The morphology of the scolex of Rhoptrobothrium, as described by Shipley and Hornell (1906), clearly marks it as a unique taxon among elasmobranch tapeworms even in the absence of data on proglottid anatomy. In the generic diagnosis Shipley and Hornell (1906; p. 58) described the scolex as consisting of a "Head with four bothridia surrounding a myzorhynchus which carries four suckers. Bothridia stalked and leaf-like, with the terminal end cut off and forming an areola." In the description of $R$. myliobatidis, they described the myzorhynchus in more detail as bearing "four rather leaf-like suckers whose edges are curled inwards, and bear half-way along their edge a pair of inwardly directed projections" (p. 59). The illustration of $R$. myliobatidis provided by Shipley and Hornell (1906) is equally intriguing (see Fig. 1C). Unfortu- nately, the place of deposition of the type material was not given by Shipley and Hornell (1906), and museum inquiries failed to locate type material, and thus, this scolex morphology could not be confirmed by examination of type material.

Two other genera, with scolex morphologies resembling that of Rhoptrobothrium, were also described by Shipley and Hornell (1906). Both Myzocephalus Shipley et Hornell, 1906 (see Fig. 1A) and Myzophyllobothrium Shipley et Hornell, 1906 (see Fig. 1B) were described as parasites of the spotted eagle ray, Aetobatus narinari (Euphrasen), also from Sri Lanka. The location of the type material of the type species of both of these genera is equally problematic. Nonetheless, a number of decisions about the taxonomic status of these genera have subsequently been made in the absence of additional material. In his monograph on the Tetraphyllidea Southwell (1925) placed Rhoptrobothrium in synonymy with Myzophyllobothrium the diagnosis of which appeared several pages before that of Rhoptrobothrium in Shipley and Hornell (1906). Southwell argued that

Address for correspondence: K. Jensen, Department of Ecology and Evolutionary Biology and the Natural History Museum and Biodiversity Research Center, University of Kansas, 1200 Sunnyside Ave., Lawrence, Kansas 66045, USA. Phone: ++1 7858645826 ;

Fax: ++1 78586458 26; E-mail: kjensen@tapeworms.org 
the type species of Rhoptrobothrium, R. myliobatidis, was actually an immature form of Myzophyllobothrium rubrum Shipley et Hornell, 1906, the type species of Myzophyllobothrium. Southwell (1930), Wardle and McLeod (1952), Yamaguti (1959) and Schmidt (1986) subsequently supported this synonymy. Euzet (1994), in the most recent taxonomic treatment of tetraphyllidean genera, however, considered Rhoptrobothrium to be a genus inquirendum. He placed Myzocephalus and Myzophyllobothrium, along with Thysanocephalum Linton, 1889 , in the subfamily Thysanocephalinae, characterized by the possession of a metascolex that was either tetralobed or crumpled.

All three of Shipley and Hornell's (1906) genera remain poorly known and consequently their unusual scolex morphologies remain poorly understood. Two additional genera, recognized in the Thysanocephalinae by Euzet (1994), were described more recently. Shindeobothrium Shinde et Chincholikar, 1975, was considered as a genus inquirendum in the Thysanocephalinae by Euzet (1994). Euzet (1994) suggested its suppression, due mainly to an incomplete description and unknown host species. As a consequence, Shindeobothrium will not be considered further. Mixophyllobothrium Shinde et Chincholikar, 1981 from "Trygon sephen" (= Pastinachus sephen [Forsskål]) from Ratnagiri, India was described by Shinde and Chincholikar (1981). Again, the scolex was not described in much detail. Euzet (1994) considered this taxon a junior synonym of Myzocephalus. Most recently, two specimens tentatively identified as Myzocephalus, were included in the comparative analysis of Caira et al. (2001). Southwell (1925) reported collecting a few specimens of $M y$ zophyllobothrium rubrum, elaborating on the proglottid anatomy, but provided little additional information on the scolex morphology. Rhoptrobothrium has not been reported since its original descriptions nearly a century ago.

Recent collections of tapeworms from Aetomylaeus maculatus and the banded eagle ray, Aetomylaeus niehofii (Bloch et Schneider), off Sarawak, Malaysia, resulted in the collection of specimens of several species consistent with Shipley and Hornell's (1906) original diagnosis of Rhoptrobothrium. Based on these specimens, the type species, Rhoptrobothrium myliobatidis, is redescribed from material collected from its type host, and a neotype is designated. In addition, specimens belonging to three new species of Rhoptrobothrium were collected from Aetomylaeus niehofii and are described below.

\section{MATERIALS AND METHODS}

Tapeworms were collected from two specimens of Aetomylaeus maculatus, in 2002 and in 2003, from Sematan, Sarawak, Malaysia. Worms were also collected from two specimens of Aetomylaeus niehofii, in 2002 from Mukah and in 2003 from Sematan, Sarawak, Malaysia. All rays were trawled by local fishermen. The spiral intestine from each ray was removed and opened with a longitudinal incision. Some tapeworms were removed from the spiral intestine in the field, fixed in $10 \%$ buffered formalin and transferred to $70 \%$ ethanol for storage. The opened spiral intestine was subsequently fixed in $10 \%$ buffered formalin for more detailed investigation in the laboratory.

Tapeworms were prepared for light and scanning electron microscopy according to the following protocols. Specimens prepared as whole mounts were hydrated in a graded ethanol series, stained in Delafield's haematoxylin, dehydrated in a graded ethanol series, cleared in methyl salicylate and mounted on glass slides in Canada balsam. Specimens prepared for histological sections were dehydrated in a graded ethanol series, cleared in xylene and embedded in paraffin according to conventional techniques. Serial sections were cut at 6-10 $\mu \mathrm{m}$ intervals using a TBS CUT 4060 Microtome, attached to slides with $3 \%$ sodium silicate, stained with Gill's haematoxylin, counterstained with eosin, cleared in xylene and mounted on glass slides in Canada balsam. Specimens prepared for scanning electron microscopy (SEM) were hydrated in a graded ethanol series, post-fixed in $1 \%$ osmium tetroxide overnight, dehydrated in a graded ethanol series, transferred to hexamethyldisilizane (HMDS, Ted Pella Inc., Redding, California) for $15 \mathrm{~min}$, following which the excess HMDS was removed, specimens were air-dried and mounted on aluminium stubs on double-sided adhesive carbon tape. Specimens were subsequently sputter coated with 100-350 $\AA$ of gold and examined with a Hitachi S4700 field emission scanning electron microscope at the Microscopy and Imaging Facility, American Museum of Natural History in New York, New York, USA, or with a Zeiss LEO 1550 field emission scanning electron microscope at the Microscopy and Electronic Imaging Laboratory, University of Kansas, Lawrence, Kansas, USA.

The unusual scolex morphology of these worms necessitated the development of some new scolex terminology. This terminology, which is illustrated in Fig. 2, is discussed and justified below, but can be summarized as follows. The scolex consists of an anterior scolex proper and a posterior cephalic peduncle. The scolex proper bears 4 acetabula that are bothridiate in form, each consisting of a specialised anterior region loculus and a posterior main loculus. The cephalic peduncle bears 4 remi. The distal depression of a remus is termed an areola. If only a single distal depression is present, it is considered to be the primary areola; if two depressions are present, the distal feature is considered to be the primary areola and the proximal one the secondary areola. All measurements of reproductive organs were taken from mature proglottids and are given in micrometres $(\mu \mathrm{m})$ unless specified. Measurements are given in the description as the range followed in parentheses by the mean, standard deviation, the number of worms examined and the total number of observations when more than one measurement was taken per worm. Illustrations were prepared with the aid of a drawing tube. Museum abbreviations used are as follows: BMNH, The Natural History Museum, London, UK; HWML, Harold W. Manter Laboratory, University of Nebraska State Museum, Lincoln, Nebraska, USA; IPASCR, Institute of Parasitology, Academy of Sciences of the Czech Republic, České Budějovice, Czech Republic; KUNHM, University of Kansas Natural History 
Museum and Biodiversity Research Center, Lawrence, Kansas, USA; LRP, Lawrence R. Penner Parasitology Collection, Department of Ecology and Evolutionary Biology, University of Connecticut, Storrs, Connecticut, USA; MHNG, Muséum d'Histoire Naturelle Genève, Geneva, Switzerland; MPM, Meguro Parasitological Museum, Tokyo, Japan; MZUM(P), Muzium Zoologi, Universiti Malaya, Kuala Lumpur, Malaysia; NMW, Naturhistorisches Museum Wien, Vienna, Austria; SBC, Sarawak Biodiversity Center, Kuching, Sarawak, Malaysia; USNPC, United States National Parasite Collection, Beltsville, Maryland, USA.

\section{RESULTS}

Rhoptrobothrium myliobatidis Shipley et Hornell, 1906 Figs. 1A, 3-17

Description (based on 10 whole mounts, 1 strobila cross-section series and 2 specimens prepared for SEM): Worms 1,429-3,368 (2,270 $\pm 828.8 ; 7)$ long, with $6-14(9 \pm 2.5 ; 10)$ proglottids, euapolytic (Fig. 3). Scolex 158-365 (216 $\pm 58.8 ; 10)$ long, consisting of 4 acetabula and cephalic peduncle with 4 stalked remi (Figs. 4, 8) (see Fig. 2 for terminology). Scolex proper $118-180(149 \pm 20.3 ; 10)$ long by $128-197(163 \pm 22.3$; 10) wide. Acetabulum bothridiate in form, with specialised anterior region in form of loculus and undivided main loculus; anterior region loculus 55-85 (72 \pm 8.3 ; $10 ; 19)$ long by $60-83(70 \pm 6.7 ; 10 ; 20)$ wide; main loculus $58-93(75 \pm 11.5 ; 9 ; 17)$ long by $48-93(71 \pm$ $12.3 ; 10 ; 18)$ wide. Cephalic peduncle pre remi length and width too short to measure, in one specimen 42 long by 78 wide. Stalked remus with primary areola only; remus (including stalk) 164-263 (215 $\pm 32.7 ; 7 ; 13)$ long; stalk short, $29-56(41 \pm 9.1 ; 7 ; 10)$ wide; remus $68-143(93 \pm 18.4 ; 10 ; 19)$ wide; primary areola $43-88$ $(64 \pm 15.2 ; 9 ; 17)$ long by $55-93(70 \pm 10.3 ; 10 ; 18)$ wide. Cephalic peduncle post remi $31-112(68 \pm 33.9$; 9) long.

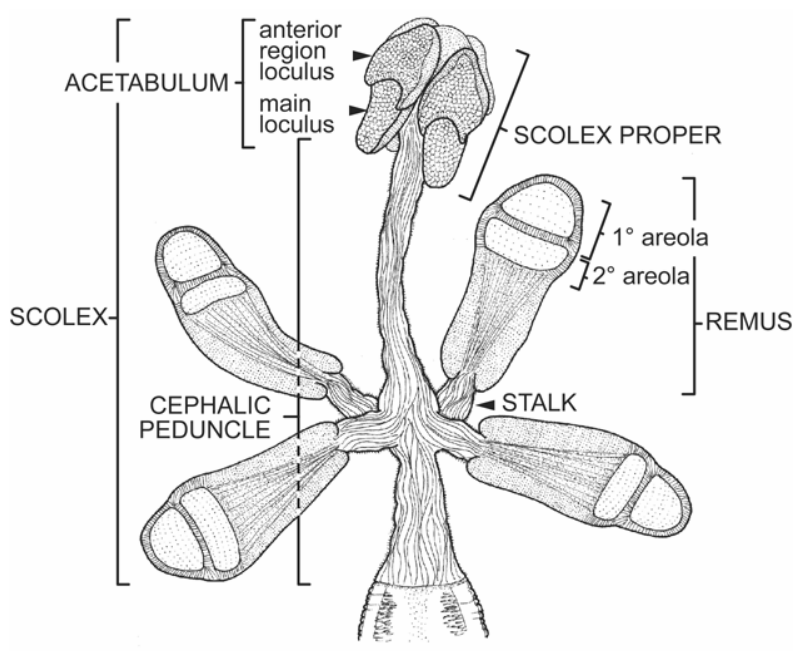

Fig. 2. Scolex terminology.
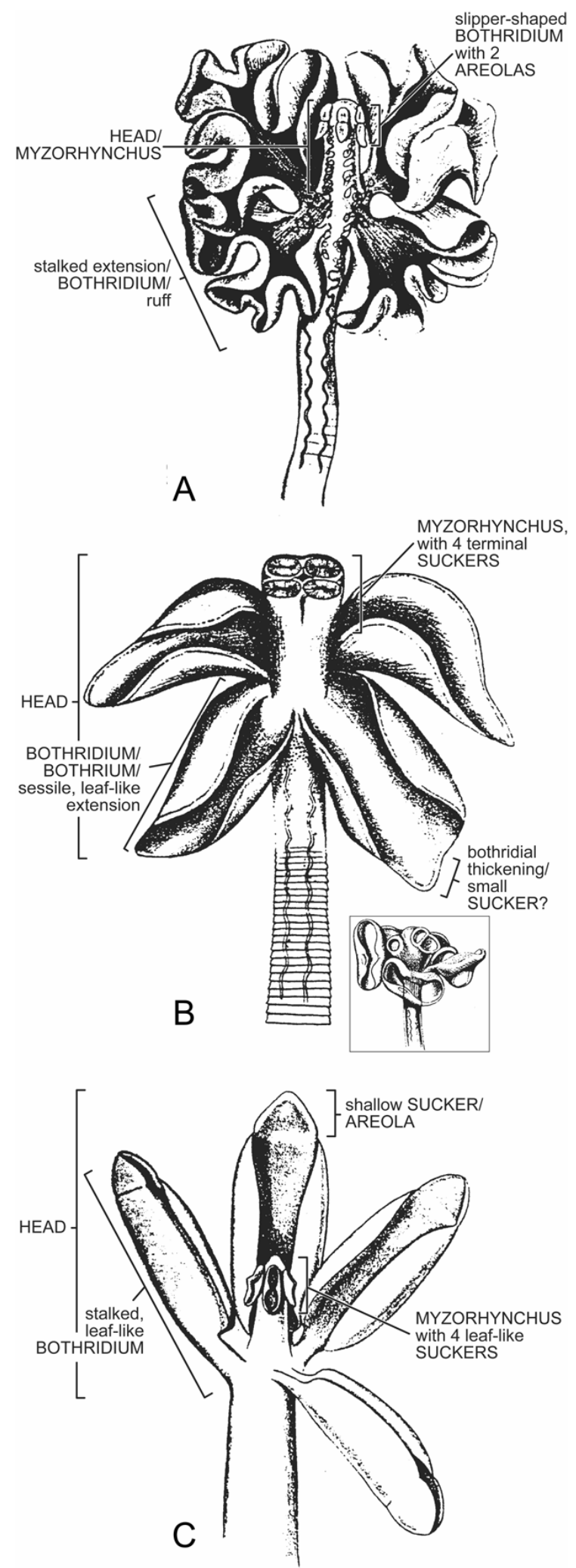

Fig. 1. Figures and scolex terminology from the original descriptions. (Taken from Shipley and Hornell 1906.) A. Myzocephalus narinari (fig. 15). B. Myzophyllobothrium rubrum (fig. 21). Note inset showing alternative scolex representation (fig. 18). C. Rhoptrobothrium myliobatidis (fig. 48). 

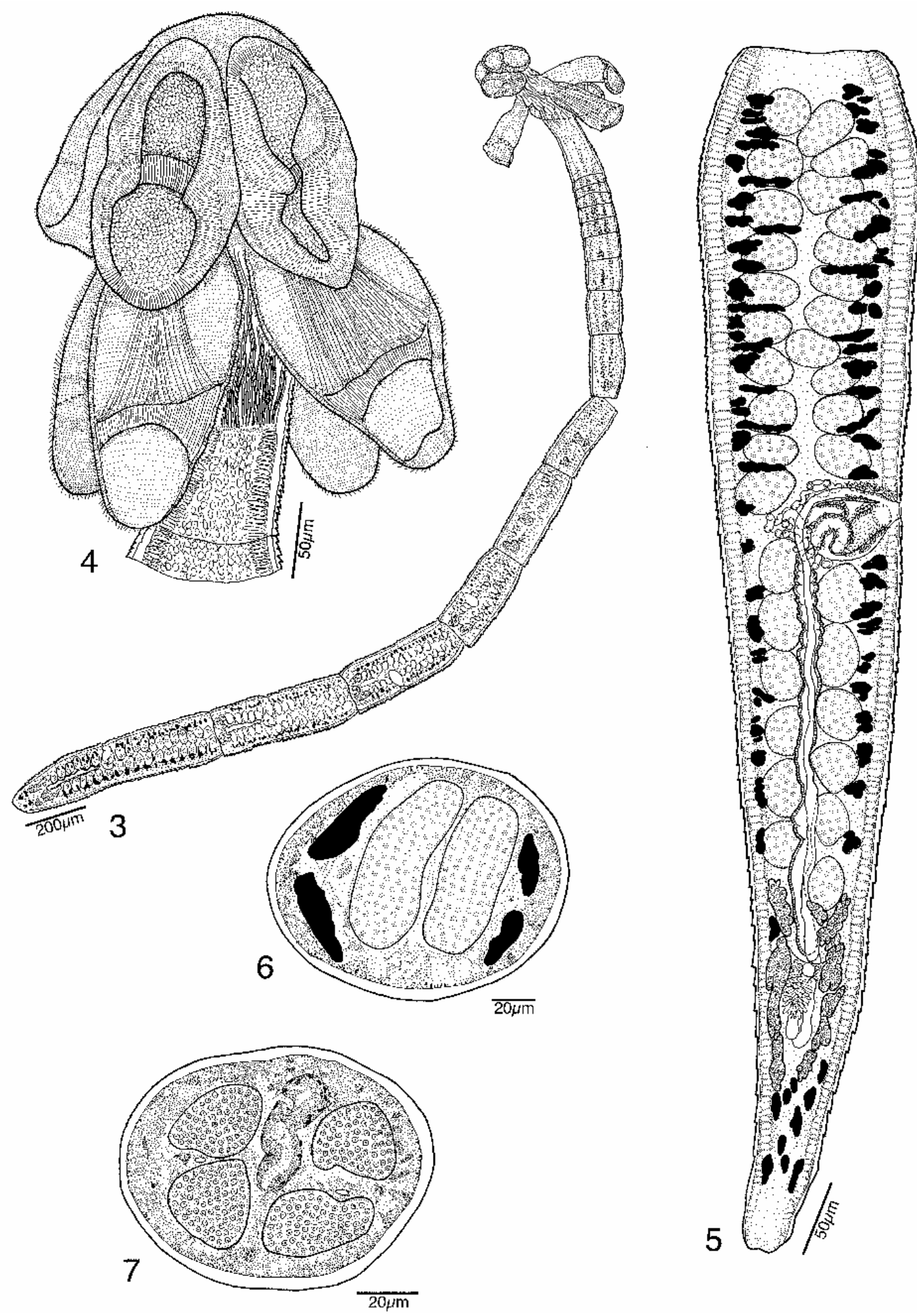

Figs. 3-7. Line drawings of Rhoptrobothrium myliobatidis Shipley et Hornell, 1906. Fig. 3. Whole worm (neotype, MZUM[P] 136). Fig. 4. Scolex (voucher, USNPC 96997). Fig. 5. Terminal, mature proglottid (voucher, USNPC 96997). Fig. 6. Crosssection through mature proglottid at level of testes (anterior to the cirrus sac) (voucher, USNPC 96998). Fig. 7. Cross-section through mature proglottid at level of ovary (slightly posterior to ovarian bridge) (voucher, USNPC 96998). 

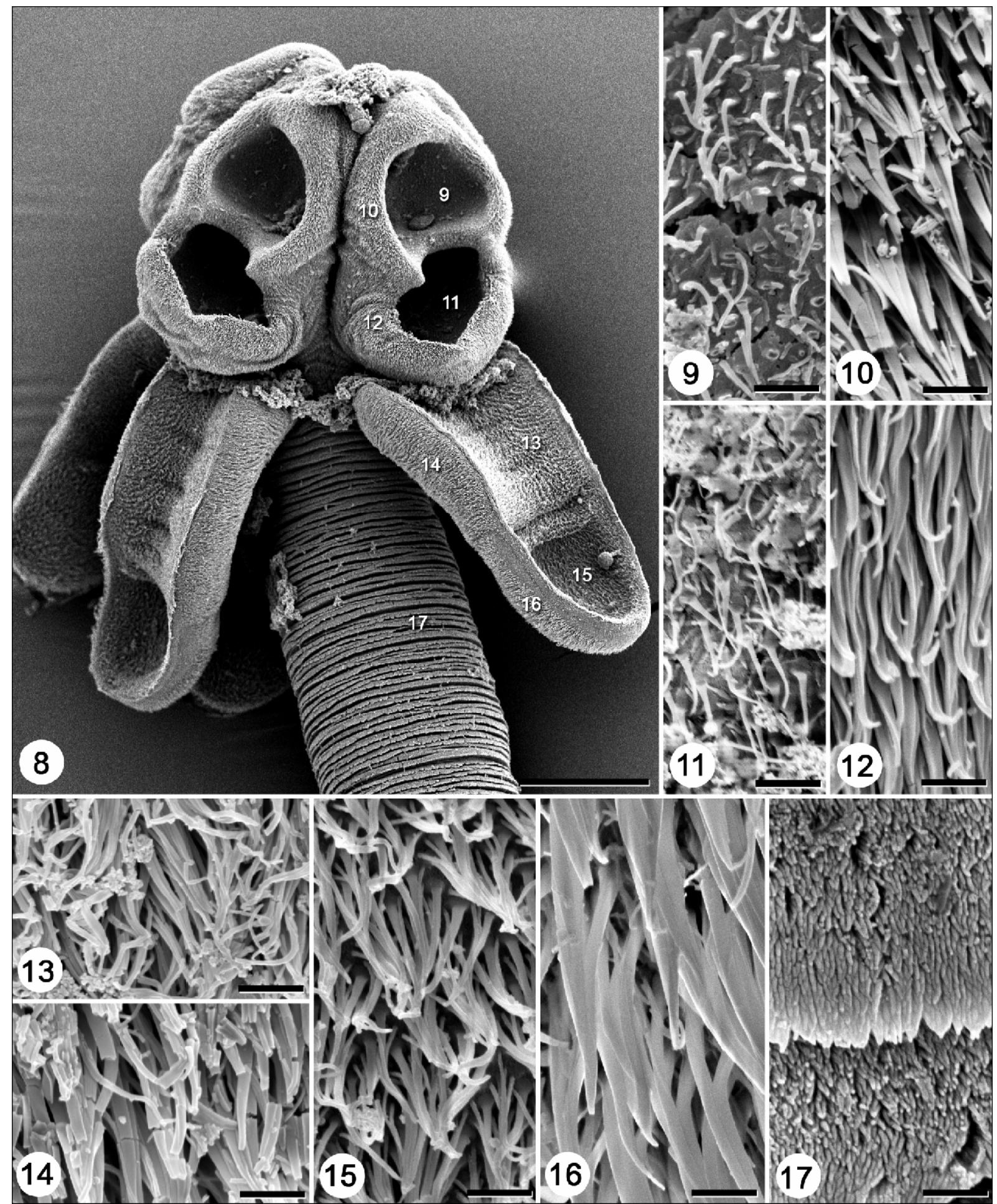

Figs. 8-17. Scanning electron micrographs of Rhoptrobothrium myliobatidis Shipley et Hornell, 1906. Fig. 8. Scolex. Note: Numbers correspond to the figures showing higher magnification images of these surfaces. Fig. 9. Microtriches on distal acetabular surface of anterior region loculus. Fig. 10. Microtriches on proximal acetabular surface of anterior region loculus. Fig. 11. Microtriches on distal acetabular surface of main loculus. Fig. 12. Microtriches on proximal acetabular surface of main loculus. Fig. 13. Microtriches on distal surface of remus. Fig. 14. Microtriches on proximal surface of remus. Fig. 15. Microtriches on distal surface of primary areola. Fig. 16. Microtriches on proximal surface of primary areola. Fig. 17. Microtriches on immature proglottid. Scale bars: Fig. $8=50 \mu \mathrm{m}$; Figs. $9-17=1 \mu \mathrm{m}$. 
Distal surfaces of anterior region loculus and main loculus covered with small blade-like spinitriches and moderately short filitriches (Figs. 9, 11, respectively); proximal surfaces of anterior region loculus and main loculus covered with long blade-like spinitriches and long filitriches (Figs. 10, 12, respectively). Distal and proximal surfaces of remus (Figs. 13, 14, respectively), and distal and proximal surfaces of areola (Figs. 15, 16, respectively) covered with long blade-like spinitriches and long filitriches. Strobila covered with long filitriches (Fig. 17).

Proglottids acraspedote. Immature proglottids 5-12 $(8 \pm 2.4 ; 7)$ in number, initially wider than long, becoming longer than wide with maturity; posterior-most immature proglottids $205-520(343 \pm 97.3 ; 10)$ long by $105-185(136 \pm 23.3 ; 10)$ wide. Mature proglottids $1-2$ in number, $360-1,000(567 \pm 170.5 ; 10 ; 13)$ long by $105-210(163 \pm 27.1 ; 10 ; 13)$ wide. Testes $27-38(33 \pm$ $3.2 ; 9 ; 16)$ in number, $12-45(26 \pm 8.1 ; 8 ; 16)$ long by $23-56(43 \pm 8.9 ; 8 ; 16)$ wide, extending from anterior margin of proglottid to ovary, slightly overlapping anterior margins of ovary, 2 columns in dorso-ventral view (Fig. 5), postvaginal testes present on poral side, 1 row deep in cross-section (Fig. 6), postovarian testes absent. Vas deferens in form of thin tube, coiling anterior to and at level of cirrus sac. External seminal vesicle absent. Internal seminal vesicle absent. Cirrus sac piriform, horizontally oriented in proglottid, 53-104 (84 \pm 14.3 ; $8 ; 11)$ long by $29-58(42 \pm 9.5 ; 8 ; 11)$ wide, containing coiled cirrus. Cirrus armed. Ovary H-shaped in dorsoventral view, tetralobed in cross-section (Fig. 7), 45$153(83 \pm 39.2 ; 8 ; 9)$ long by $40-104(81 \pm 20.5 ; 8 ; 9)$ wide, lobulated, symmetrical; ovarian bridge slightly anterior to centre of ovary. Vagina looping between posterior lobes of ovary, then extending anteriorly from ootype region to genital pore, not crossing cirrus sac, opening anterior to cirrus sac into genital atrium; vaginal sphincter absent. Genital pore lateral, 40-61\% (50 \pm $6.7 ; 10 ; 13)$ of proglottid length from posterior end; genital pores irregularly alternating along length of strobila. Uterus saccate, extending along midline of proglottid from level anterior to ovary to level of posterior margin of cirrus sac, ventral to vagina; uterine duct not observed; uterine pore absent. Vitellaria follicular, medullary, lateral, extending entire length of proglottid, essentially interrupted by ovary, and dorsally and ventrally by cirrus sac; vitelline follicles 5-19 $(11 \pm 3.8 ; 8$; 16) long by $7-42(18 \pm 9.9 ; 8 ; 16)$ wide; 1 dorsal and 1 ventral column on each side of proglottid (Fig. 6). Eggs not observed. One dorsal and one ventral pair of excretory vessels.

T y p e h o s t: Aetomylaeus maculatus (Gray) (Myliobatiformes: Myliobatidae), the mottled eagle ray.

Ty p e loc a lity: Gulf of Manaar, Sri Lanka.

A d d i t i o n a $1 \quad 1$ o c a 1 i t y : Sematan $\left(01^{\circ} 48^{\prime} \mathrm{N}\right.$, $\left.109^{\circ} 46^{\prime} \mathrm{E}\right)$, Sarawak, Malaysia.
D a t e of c o 11 e ct i o n : June 03, 2002 (host specimen BO-22); May 15, 2003 (host specimen BO-178).

$\mathrm{S}$ ite of infection: Spiral intestine.

Type materia1: Neotype (MZUM[P] 136).

Additiona $1 \mathrm{~m}$ a t e ria $1: 1$ voucher (SBC-C-00004); 1 voucher (IPASCR C-430); 6 vouchers (4 whole mounts, 1 strobila cross-section series) (USNPC 96997, 96998); 9 vouchers (LRP 3803, 3804); 2 vouchers (prepared for SEM) (KUNHM, senior author's collection).

\section{Remarks}

Given that Shipley and Hornell (1906) did not indicate the designation or the deposition of type material, and inquiries at a diversity of museums (e.g., BMNH, MHNG, MPM, NMW, USNPC, HWML) have been unsuccessful in locating type material of $R$. myliobatidis, it should be considered lost. Moreover, to our knowledge, no subsequently collected material of this species exists that could be examined for additional information. The confusion surrounding the identity of this genus necessitates the designation of a neotype. Our specimens were collected from the type host, Aetomylaeus maculatus, and are consistent with Shipley and Hornell's (1906) illustration (see Fig. 1) and, albeit, limited description of the type species, Rhoptrobothrium myliobatidis (e.g., the scolex is minute and measures 1.8 $\mathrm{mm}$ long by $1 \mathrm{~mm}$ wide from "tip to tip" when the "arms" were stretched). Although the neotype did not come from the type locality, the island of Borneo is at least of relatively close proximity to Sri Lanka.

\section{Rhoptrobothrium chongi sp. n.}

Figs. 18-34

Description (based on 8 whole mounts, 1 scolex longitudinal section series and 2 specimens prepared for SEM): Worms 1,408-1,842 (1,627 $\pm 195.3 ; 5)$ long, with $5-8(6 \pm 1.1 ; 5)$ proglottids, euapolytic (Fig. 18). Scolex 160-460 (331 $\pm 103.5 ; 8)$ long, consisting of 4 acetabula and cephalic peduncle with 4 stalked remi (Figs. 19, 22). Scolex proper 128-150 (138 $\pm 9.4 ; 8)$ long by $105-148(128 \pm 12.2 ; 8)$ wide. Acetabulum bothridiate in form, with specialised anterior region in form of loculus and undivided main loculus; anterior region loculus $58-88(75 \pm 7.2 ; 8 ; 15)$ long by $53-63$ $(60 \pm 3.4 ; 8 ; 10)$ wide; main loculus $55-83(67 \pm 6.3 ; 8$; $16)$ long by $35-50(40 \pm 5.2 ; 7 ; 10)$ wide. Cephalic peduncle pre remi $67-226(137 \pm 55.8 ; 8)$ long by $25-65$ $(41 \pm 14.7 ; 8)$ wide. Stalked remus with primary and secondary areola; remus (including stalk) 213-335 (265 $\pm 38.1 ; 6$; 12) long; stalk long, 25-43 (32 $\pm 5.0 ; 8 ; 15)$ wide; remus $55-103(75 \pm 17.4 ; 7 ; 13)$ wide; primary areola $35-68(50 \pm 9.2 ; 8 ; 15)$ long by $55-98(75 \pm 12.2$; $8 ; 15)$ wide. Cephalic peduncle post remi 31-119 (90 \pm 30.2; 7) long.

Distal surfaces of anterior region loculus and main loculus covered with small blade-like spinitriches and moderately short filitriches (Figs. 23, 25, respectively); proximal surfaces of anterior region loculus and main 

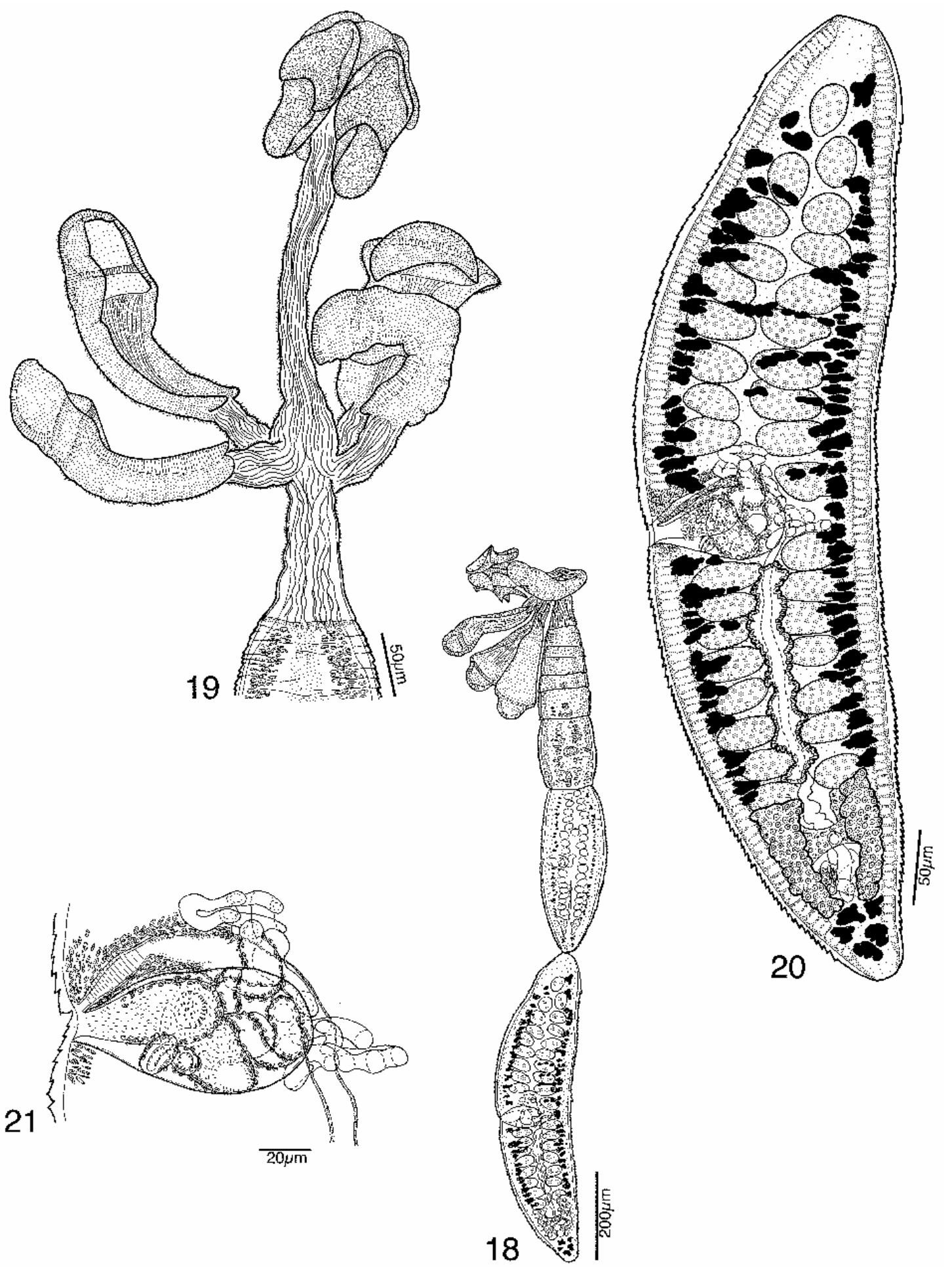

Figs. 18-21. Line drawings of Rhoptrobothrium chongi sp. n. Fig. 18. Whole worm (paratype, USNPC 96994). Fig. 19. Scolex (holotype, MZUM[P] 131). Fig. 20. Terminal, mature proglottid (paratype, USNPC 96994). Fig. 21. Detail of terminal genitalia of mature proglottid (paratype, USNPC 96994).

loculus covered with long blade-like spinitriches and long filitriches (Figs. 24, 26, respectively). Apex of scolex proper covered with long filitriches only (Fig. 27). Cephalic peduncle pre and post remi (Figs. 28, 29, respectively), stalks (Fig. 33), distal and proximal sur- faces of remus (Figs. 30, 31, respectively), and proximal surface of areola (Fig. 32) covered with long blade-like spinitriches and long filitriches. Strobila covered with long filitriches (Fig. 34). 


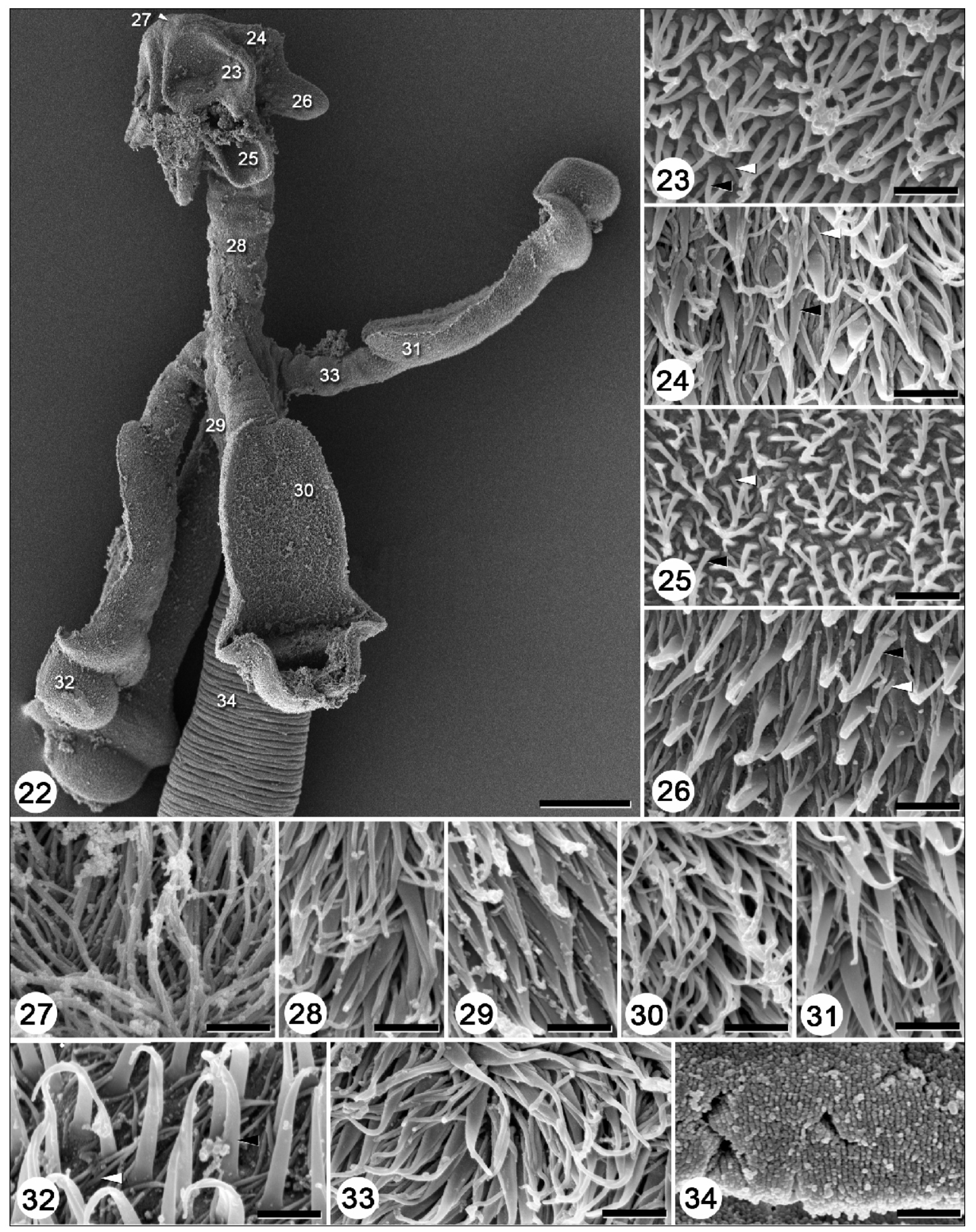

Figs. 22-34. Scanning electron micrographs of Rhoptrobothrium chongi sp. n. Fig. 22. Scolex. Note: Numbers correspond to the figures showing higher magnification images of these surfaces. Fig. 23. Microtriches on distal acetabular surface of anterior region loculus. Fig. 24. Microtriches on proximal acetabular surface of anterior region loculus. Fig. 25. Microtriches on distal acetabular surface of main loculus. Fig. 26. Microtriches on proximal acetabular surface of main loculus. Fig. 27. Microtriches on apex of scolex proper. Fig. 28. Microtriches on cephalic peduncle anterior to remi. Fig. 29. Microtriches on cephalic peduncle posterior to remi. Fig. 30. Microtriches on distal surface of remus. Fig. 31. Microtriches on proximal surface of remus. Fig. 32. Microtriches on proximal surface of primary areola. Fig. 33. Microtriches on stalk. Fig. 34. Microtriches on immature proglottid. Note: In Figs. 23-26, 32, black arrowheads indicate spinitriches and white arrowheads indicate filitriches. Scale bars: Fig. $22=$ $50 \mu \mathrm{m}$; Figs. $23-34=1 \mu \mathrm{m}$. 
Proglottids acraspedote. Immature proglottids 4-7 (5 $\pm 1.3 ; 5$ ) in number, initially wider than long, becoming longer than wide with maturity; posterior-most immature proglottids $178-430(283 \pm 99.1 ; 7)$ long by $105-$ $170(138 \pm 21.2 ; 7)$ wide. Mature proglottids $1-2$ in number, $320-675(513 \pm 145.5 ; 5 ; 7)$ long by $140-190$ $(165 \pm 18.3 ; 5 ; 7)$ wide. Testes $22-37(31 \pm 4.7 ; 6 ; 10)$ in number, $20-43(26 \pm 7.0 ; 5 ; 10)$ long by $31-49(42 \pm$ 5.8 ; 5 ; 10) wide, extending from anterior margin of proglottid to ovary, slightly overlapping anterior margins of ovary, 2 columns in dorso-ventral view (Fig. 20), postvaginal testes present on poral side, 1 row deep, postovarian testes absent. Vas deferens in form of thin tube, coiling anterior to and at level of cirrus sac. External seminal vesicle absent. Internal seminal vesicle absent. Cirrus sac piriform, horizontally oriented in proglottid, $70-95(83 \pm 11.6 ; 5)$ long by $37-53$ (46 \pm $6.2 ; 5)$ wide, containing coiled cirrus. Cirrus armed. Ovary H-shaped in dorso-ventral view, tetralobed in cross-section, $61-90(73 \pm 12.4 ; 5)$ long by $67-89$ (78 \pm 9.3 ; 4) wide, lobulated, symmetrical; ovarian bridge at or slightly anterior to centre of ovary. Vagina looping between posterior lobes of ovary, then extending anteriorly from ootype region to genital pore, not crossing cirrus sac, opening anterior to cirrus sac into genital atrium; muscles surrounding distal portion of vagina visible (Fig. 21), but true vaginal sphincter absent. Genital pore lateral, $44-60 \%(51 \pm 5.4 ; 5 ; 7)$ of proglottid length from posterior end; genital pores irregularly alternating along length of strobila. Uterus saccate, extending along midline of proglottid from level anterior to ovary to level of posterior margin of cirrus sac; uterine duct not observed; uterine pore absent. Vitellaria follicular, medullary, lateral, extending entire length of proglottid, interrupted by ovary, and dorsally and ventrally by cirrus sac; vitelline follicles $5-16(11 \pm 3.8 ; 5$; 10) long by $5-38(20 \pm 8.6 ; 5 ; 10)$ wide; essentially 1 dorsal and 1 ventral column on each side of proglottid. Eggs not observed. One dorsal and one ventral pair of excretory vessels.

$\mathrm{T}$ y p e h o s t: Aetomylaeus niehofii (Bloch et Schneider) (Myliobatiformes: Myliobatidae), the banded eagle ray.

T y p e 1 o c a 1 i t y : Mukah $\left(02^{\circ} 54^{\prime} \mathrm{N}, 112^{\circ} 06^{\prime} \mathrm{E}\right)$, Sarawak, Malaysia.

D a t e of colle cti o n: June 08, 2002 (host specimen BO-34).

Site of infection: Spiral intestine.

Ty p e materia 1: Holotype (MZUM[P] 131), 1 paratype (MZUM[P] 132); 1 paratype (SBC-C-00001); 4 paratypes (3 whole mounts, 1 scolex longitudinal section series) (USNPC 96994); 2 paratypes (LRP 3797, 3798); 2 paratypes (prepared for SEM) (KUNHM, senior author's collection).

E t y m o 1 o g y : This species is named in honour of George Chong, without whose logistical assistance and perseverance our collections in Sarawak would not have been possible.

\section{Remarks}

Rhoptrobothrium chongi is easily distinguished from R. myliobatidis based on the configuration of the remi; while a secondary areola is present on the remi of $R$. chongi a secondary areola is lacking in $R$. myliobatidis. In addition, the remi in $R$. chong $i$ are conspicuously stalked and the cephalic peduncle anterior to the remi is extensive, while the remi in $R$. myliobatidis are very short, almost sessile, and the cephalic peduncle anterior to the remi is usually so short it is difficult to measure. In general, $R$. chongi also has fewer proglottids than $R$. myliobatidis (4-8 vs. 6-14) and a narrower loculus on the acetabulum (35-50 vs. 48-93). Rhoptrobothrium chongi parasitizes $A$. niehofii, a congener of the type host of $R$. myliobatidis.

\section{Rhoptrobothrium gambangi sp. n.}

Figs. 35-50

Description (based on 9 whole mounts, 2 whole worm cross-section series, 1 whole worm longitudinal section series and 1 specimen prepared for SEM): Worms 1,110-2,081 (1,557 \pm 323.5 ; 9) long, with 5-14 $(7 \pm 2.7 ; 9)$ proglottids, euapolytic. Scolex 153-280 (216 \pm 40.9 ; 9) long, consisting of 4 acetabula and cephalic peduncle with 4 stalked remi (Figs. 36, 40). Scolex proper $111-135(123 \pm 8.0 ; 9)$ long by $95-133$ $(113 \pm 11.9 ; 9)$ wide. Acetabulum bothridiate in form, with specialised anterior region in form of loculus and undivided main loculus; anterior region loculus 57-83 $(67 \pm 7.4 ; 9 ; 17)$ long by $42-63(53 \pm 5.6 ; 8 ; 15)$ wide; main loculus $51-73(60 \pm 7.3 ; 9 ; 16)$ long by $30-49$ (42 $\pm 5.3 ; 8 ; 14)$ wide. Cephalic peduncle pre remi $18-82$ $(46 \pm 26.4 ; 8)$ long by $44-117(70 \pm 24.3 ; 8)$ wide. Stalked remus with primary and secondary areola; stalk short, 32-50 (41 $\pm 6.6 ; 8 ; 13)$ wide; remus 69-108 (85 \pm $11.4 ; 7 ; 12)$ wide; primary areola $32-65(45 \pm 8.9 ; 9$; $15)$ long by $49-80(64 \pm 9.4 ; 9 ; 15)$ wide. Cephalic peduncle post remi $27-52(41 \pm 7.5 ; 9)$ long.

Distal surfaces of anterior region loculus and main loculus covered with small blade-like spinitriches and moderately short filitriches (Figs. 41, 43, respectively); proximal surfaces of anterior region loculus and main loculus covered with long blade-like spinitriches and long filitriches (Figs. 42, 44, respectively). Apex of scolex proper covered with long filitriches only (Fig. 47). Cephalic peduncle pre and post remi (Figs. 48, 49, respectively) and proximal surfaces of remus and areola (Figs. 45, 46, respectively) covered with long blade-like spinitriches and long filitriches. Strobila covered with long filitriches (Fig. 50).

Proglottids acraspedote. Immature proglottids 3-7 (5 \pm 1.3 ; 9) in number, initially wider than long, becoming longer than wide with maturity; posterior-most immature proglottids $208-386(275 \pm 61.1 ; 9)$ long by 110 $150(126 \pm 14.1 ; 9)$ wide. Mature proglottids $1-2$ in number, $382-730(526 \pm 121.8 ; 9 ; 11)$ long by $115-190$ $(154 \pm 24.1 ; 9 ; 11)$ wide. Testes $22-36(28 \pm 3.7 ; 9 ; 18)$ 

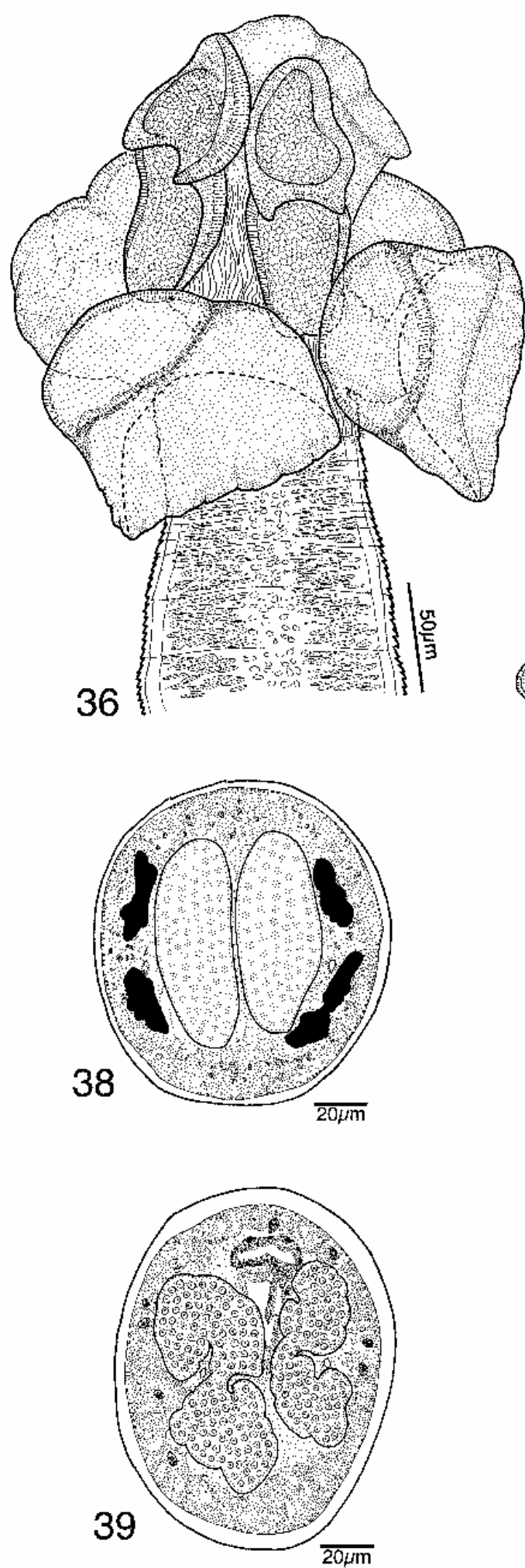
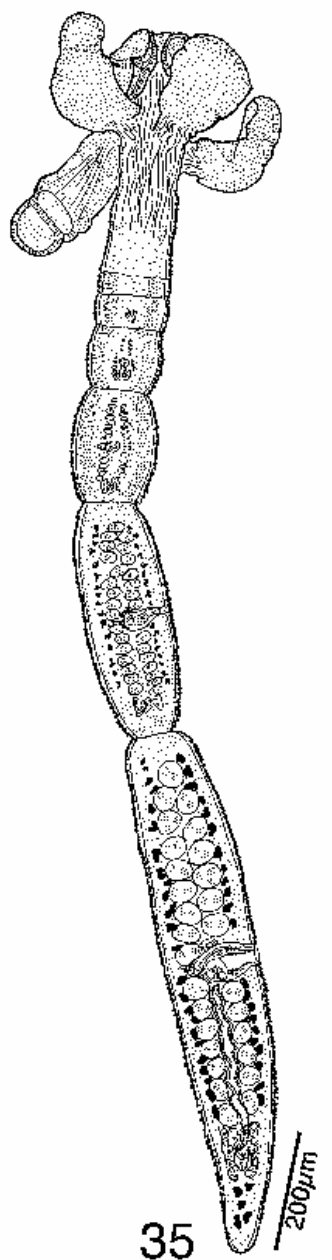

35

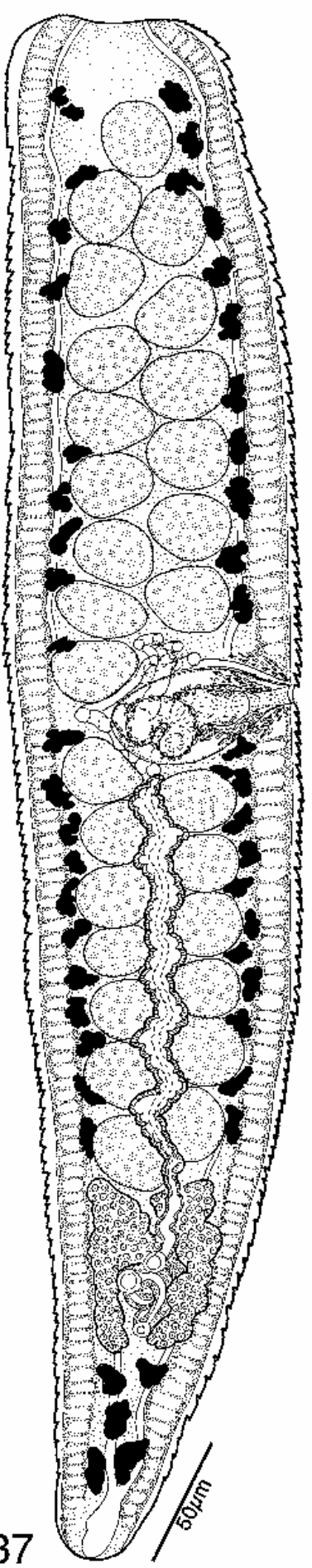

Figs. 35-39. Line drawings of Rhoptrobothrium gambangi sp. n. Fig. 35. Whole worm (paratype, USNPC 96995). Fig. 36. Scolex (holotype, MZUM[P] 133). Fig. 37. Terminal, mature proglottid (paratype, USNPC 96995). Fig. 38. Cross-section through mature proglottid at level of testes (anterior to the cirrus sac) (paratype, USNPC 96995). Fig. 39. Cross-section through mature proglottid at level of ovary (slightly anterior to ovarian bridge) (paratype, USNPC 96995). 

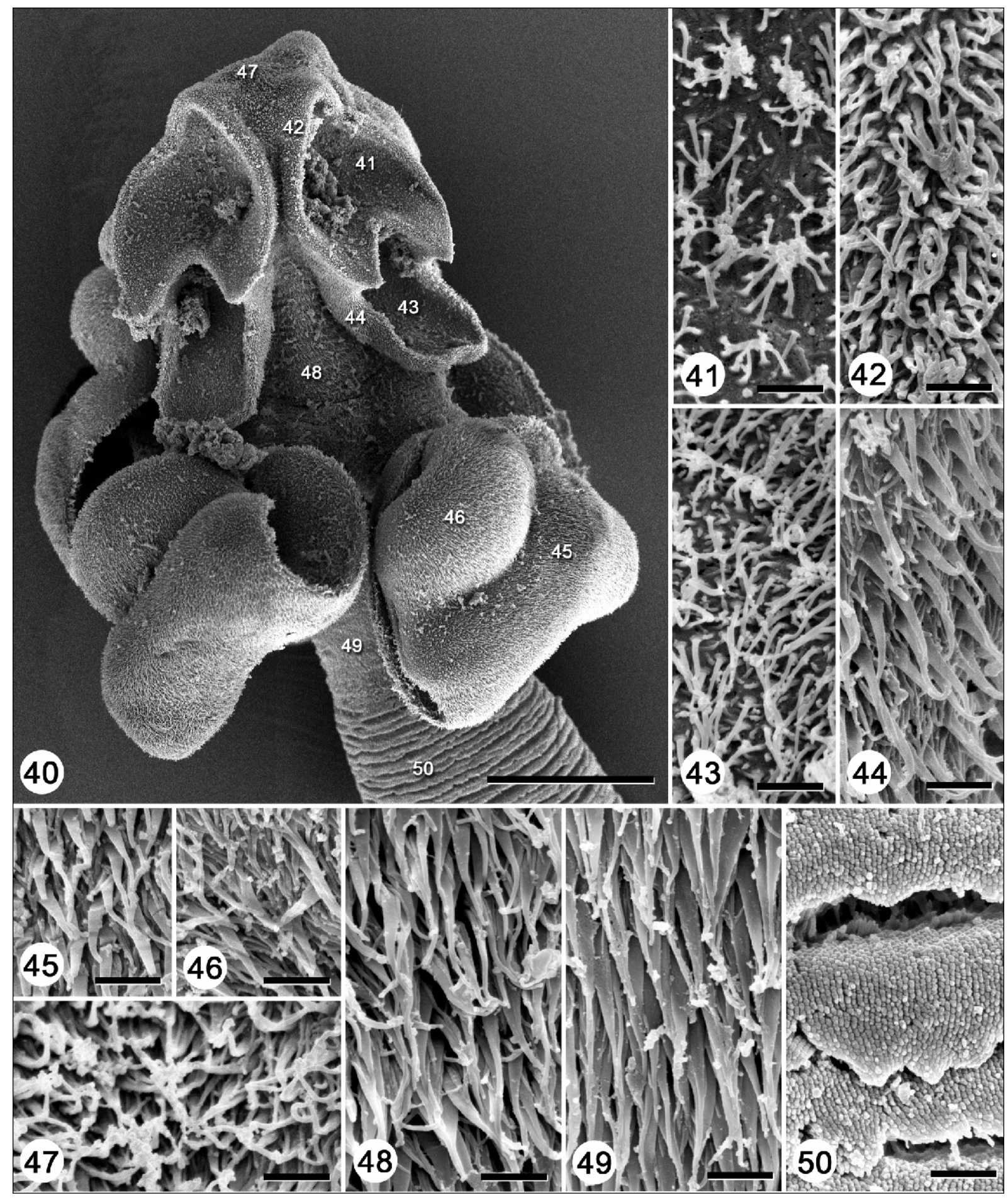

Figs. 40-50. Scanning electron micrographs of Rhoptrobothrium gambangi sp. n. Fig. 40. Scolex. Note: Numbers correspond to the figures showing higher magnification images of these surfaces. Fig. 41. Microtriches on distal acetabular surface of anterior region loculus. Fig. 42. Microtriches on proximal acetabular surface of anterior region loculus. Fig. 43. Microtriches on distal acetabular surface of main loculus. Fig. 44. Microtriches on proximal acetabular surface of main loculus. Fig. 45. Microtriches on proximal surface of remus. Fig. 46. Microtriches on proximal surface of primary areola. Fig. 47. Microtriches on apex of scolex proper. Fig. 48. Microtriches on cephalic peduncle anterior to remi. Fig. 49. Microtriches on cephalic peduncle posterior to remi. Fig. 50. Microtriches on immature proglottid. Scale bars: Fig. $40=50 \mu \mathrm{m}$; Figs. $41-50=1 \mu \mathrm{m}$. 
in number, $15-44(28 \pm 7.9 ; 9 ; 18)$ long by $20-56(43 \pm$ $9.8 ; 9 ; 18)$ wide, extending from anterior margin of proglottid to ovary, slightly overlapping anterior margins of ovary, 2 columns in dorso-ventral view, postvaginal testes present on poral side, 1 row deep in crosssection (Fig. 38), postovarian testes absent. Vas deferens in form of thin tube, coiling anterior to and at level of cirrus sac. External seminal vesicle absent. Internal seminal vesicle absent. Cirrus sac piriform, horizontally oriented in proglottid, $57-92(76 \pm 12.0 ; 9)$ long by 30 $68(49 \pm 12.0 ; 9)$ wide, containing coiled cirrus. Cirrus armed. Ovary H-shaped in dorso-ventral view, tetralobed in cross-section (Fig. 39), 39-101 (74 \pm 18.7 ; 9) long by $50-106(83 \pm 19.5 ; 9)$ wide, lobulated, symmetrical; ovarian bridge approximately at centre of ovary. Vagina looping between posterior lobes of ovary, then extending anteriorly from ootype region to genital pore, not crossing cirrus sac, opening anterior to cirrus sac into genital atrium; vaginal sphincter absent. Genital pore lateral, $48-58 \%(53 \pm 3.6 ; 9 ; 11)$ of proglottid length from posterior end; genital pores irregularly alternating along length of strobila. Uterus saccate, extending along midline of proglottid from level anterior to ovary to level of posterior margin of cirrus sac, ventral to vagina; uterine duct not observed; uterine pore absent. Vitellaria follicular, medullary, lateral, extending entire length of proglottid, interrupted by ovary, and dorsally and ventrally by cirrus sac; vitelline follicles 7 $22(13 \pm 4.3 ; 9 ; 18)$ long by $9-30(17 \pm 5.6 ; 9 ; 18)$ wide; 1 dorsal and 1 ventral column on each side of proglottid (Fig. 38). Eggs not observed. One dorsal and one ventral pair of excretory vessels.

$\mathrm{T}$ y $\mathrm{p}$ e $\mathrm{h}$ o s t: Aetomylaeus niehofii (Bloch et Schneider) (Myliobatiformes: Myliobatidae), the banded eagle ray.

T y p e 1 o c a 1 it y: Mukah $\left(02^{\circ} 54^{\prime} \mathrm{N}, 112^{\circ} 06^{\prime} \mathrm{E}\right)$, Sarawak, Malaysia.

A d d i t i o n a $1 \quad 1$ o c a 1 i t y : Sematan $\left(01^{\circ} 48^{\prime} N\right.$, $\left.109^{\circ} 46^{\prime} \mathrm{E}\right)$, Sarawak, Malaysia.

D a t e of colle ction: June 08, 2002 (host specimen BO-34); May 15, 2003 (host specimen BO-180).

$\mathrm{S}$ ite of infection: Spiral intestine.

T y p e mat e r i a 1: Holotype (MZUM[P] 133), 1 paratype (MZUM[P] 134); 1 paratype (SBC-C-00002); 6 paratypes (3 whole mounts, 2 whole worm cross-section series, 1 whole worm longitudinal section series) (USNPC 96995); 3 paratypes (LRP 3800-3802); 1 paratype (prepared for SEM) (KUNHM, senior author's collection).

E t y m o lo g y : This species is named in honour of Albert Gambang, Head of the Fisheries Research Institute in Kuching, Sarawak, whose cooperation and generous support through the use of his facilities greatly enhanced our work in and around Kuching.

\section{Remarks}

Rhoptrobothrium gambangi is easily distinguished from $R$. myliobatidis based on the configuration of the remi; whereas $R$. gambangi possesses a secondary areola on the remi, the secondary areola is lacking in $R$. myliobatidis. In addition, in general, both the anterior region loculus and the loculus of the acetabulum are somewhat narrower in $R$. gambangi than they are in $R$. myliobatidis (42-63 and $30-49$ vs. $60-83$ and 48-93). Rhoptrobothrium gambangi can be distinguished from $R$. chongi based on the length of the stalks of the remi and the length of the cephalic peduncle anterior to the remi; the remi in $R$. gambangi appear sessile and the cephalic peduncle anterior to the remi is short, while the remi in $R$. chongi are clearly stalked and the cephalic peduncle anterior to the remi is extensive. In addition, in general, the remi of $R$. gambangi are folded with the distal portion curled anteriorly, while the remi of $R$. myliobatidis and $R$. chongi are irregularly folded. Rhoptrobothrium gambangi is the second species in this genus to be described from Aetomylaeus niehofii.

\section{Rhoptrobothrium limae sp. $\mathrm{n}$.}

Figs. 51-68

Description (based on 6 whole mounts and 3 specimens prepared for SEM): Worms 2,420-4,970 (3,952 \pm 952.2; 5) long, with 9-22 (17 $\pm 5.1 ; 5)$ proglottids, euapolytic. Scolex $240-600(374 \pm 134.1 ; 6)$ long, consisting of 4 acetabula and cephalic peduncle with 4 stalked remi (Figs. 52, 55). Scolex proper 115-140 (129 \pm 9.7 ; 5) long by $105-135(120 \pm 13.2$; 5) wide. Acetabulum bothridiate in form, with specialised anterior region in form of loculus and undivided main loculus; anterior region loculus 56-78 $(67 \pm 6.1 ; 6 ; 12)$ long by $45-73(58 \pm 8.6 ; 5 ; 10)$ wide; main loculus $58-79$ $(70 \pm 7.2 ; 6 ; 11)$ long by $38-80(51 \pm 14.7 ; 5 ; 10)$ wide. Cephalic peduncle pre remi $30-161(77 \pm 53.3 ; 5)$ long by $59-86(73 \pm 10.8 ; 5)$ wide. Stalked remus with primary and secondary areola; remus (including stalk) 193-265 (224 $\pm 22.2 ; 6$; 9) long; stalk long; 35-94 (52 \pm $17.8 ; 6 ; 11)$ wide; remus $70-138(102 \pm 22.7 ; 6 ; 9)$ wide; primary areola $43-78(58 \pm 11.1 ; 6 ; 12)$ long by $53-95(76 \pm 15.5 ; 6 ; 12)$ wide. Cephalic peduncle post remi 62-325 (159 $\pm 107.9 ; 6)$ long.

Distal surfaces of anterior region loculus covered with small blade-like spinitriches and short filitriches (Fig. 56); distal surfaces of main loculus covered with small blade-like spinitriches and longish filitriches (Fig. 58); proximal surfaces of anterior region loculus and main loculus covered with long blade-like spinitriches and long filitriches (Figs. 57, 59, respectively). Apex of scolex proper covered with long filitriches only (Fig. 65). Cephalic peduncle pre and post remi (Figs. 61, 62, respectively), and distal and proximal surfaces of remus (Figs. 63, 64, respectively) covered with long blade-like spinitriches and long filitriches. Distal and proximal surfaces of areola covered with less dense long bladelike spinitriches and long filitriches (Figs. 66, 67, respectively). Strobila covered with long filitriches (Fig. 68).

Proglottids acraspedote. Immature proglottids 7-18 $(14 \pm 4.5 ; 5)$ in number, initially wider than long, becoming longer than wide with maturity; posterior-most 


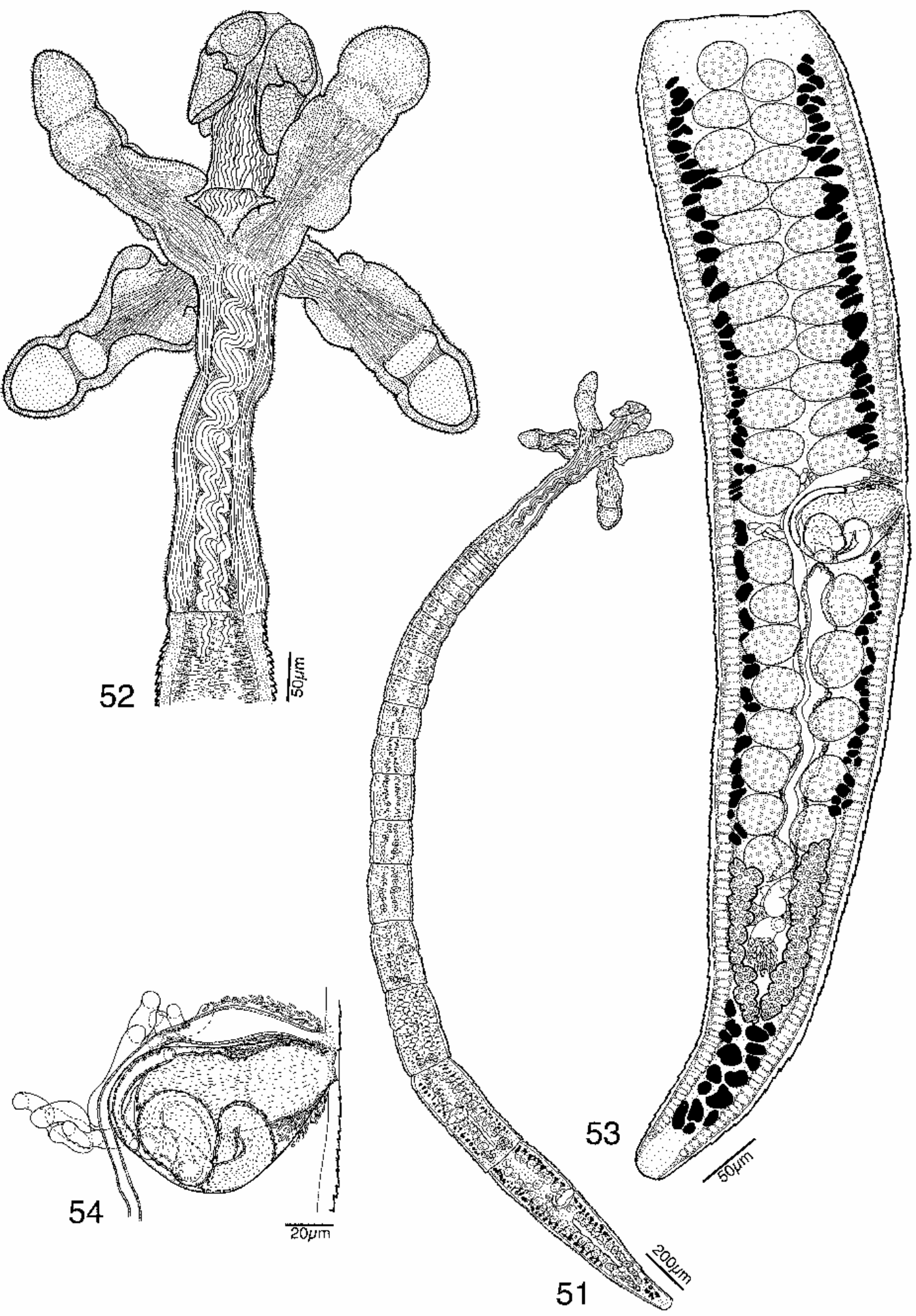

Figs. 51-54. Line drawings of Rhoptrobothrium limae sp. n. Fig. 51. Whole worm (paratype, USNPC 96996). Fig. 52. Scolex (paratype, USNPC 96996). Fig. 53. Terminal, mature proglottid (paratype, MZUM[P] 135). Fig. 54. Detail of terminal genitalia of mature proglottid (paratype, MZUM[P] 135). 

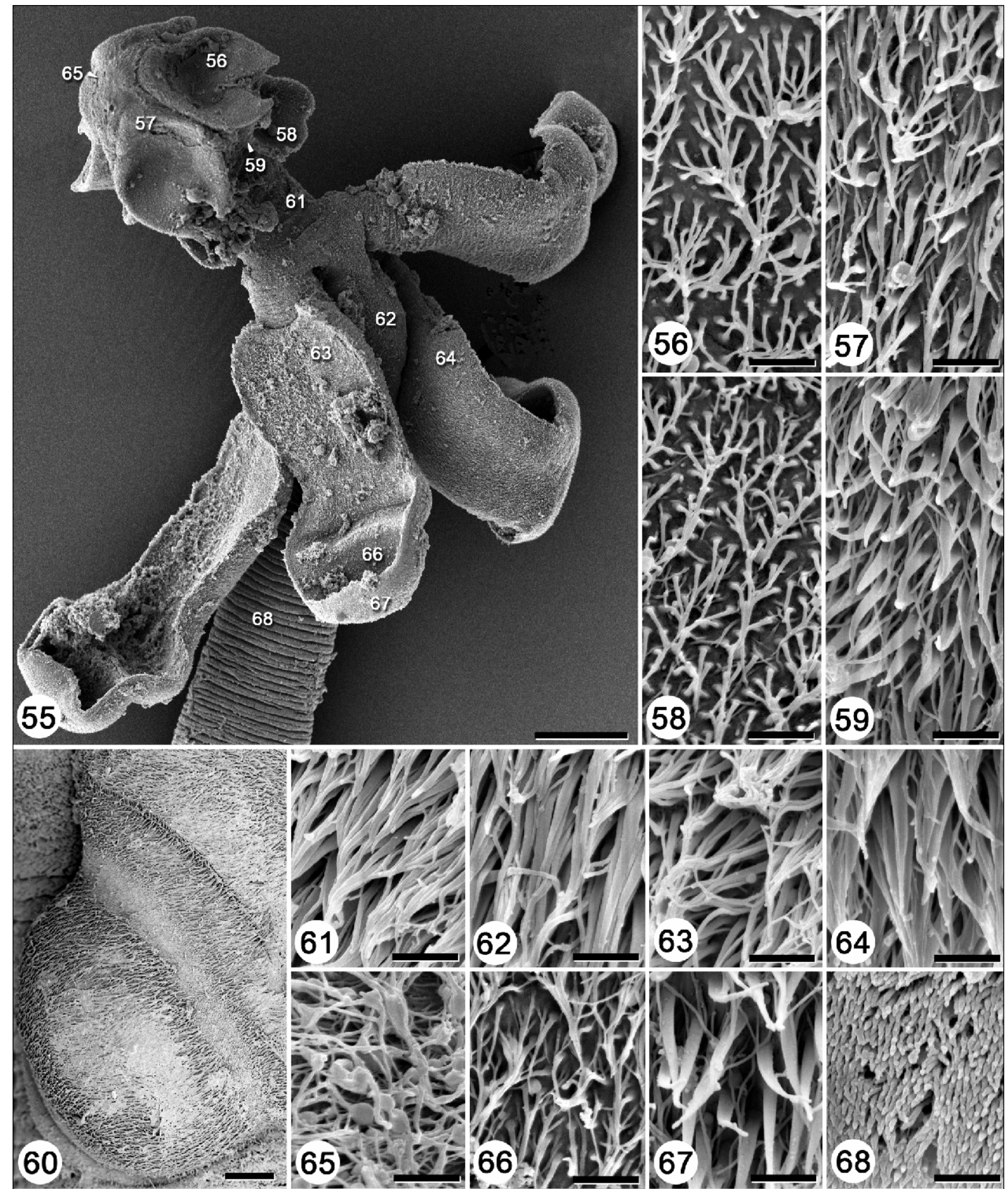

Figs. 55-68. Scanning electron micrographs of Rhoptrobothrium limae sp. n. Fig. 55. Scolex. Note: Numbers correspond to the figures showing higher magnification images of these surfaces. Fig. 56. Microtriches on distal acetabular surface of anterior region loculus. Fig. 57. Microtriches on proximal acetabular surface of anterior region loculus. Fig. 58. Microtriches on distal acetabular surface of main loculus. Fig. 59. Microtriches on proximal acetabular surface of main loculus. Fig. 60. Microthrix pattern on proximal surface of primary and secondary areola. Fig. 61. Microtriches on cephalic peduncle anterior to remi. Fig. 62. Microtriches on cephalic peduncle posterior to remi. Fig. 63. Microtriches on distal surface of remus. Fig. 64. Microtriches on proximal surface of remus. Fig. 65. Microtriches on apex of scolex proper. Fig. 66. Microtriches on distal surface of primary areola. Fig. 67. Microtriches on proximal surface of primary areola. Fig. 68. Microtriches on immature proglottid. Scale bars: Fig. $55=50 \mu \mathrm{m}$; Figs. 56-59, 61 $-68=1 \mu \mathrm{m}$; Fig. $60=10 \mu \mathrm{m}$. 
immature proglottids $245-360(312 \pm 53.0 ; 5)$ long by $140-165(150 \pm 13.2 ; 3)$ wide. Mature proglottids $2-4$ $(3 \pm 0.8 ; 5)$ in number, $420-1,010(665 \pm 220.4 ; 5 ; 10)$ long by $140-190(167 \pm 18.5 ; 5 ; 9)$ wide. Testes $28-43$ $(36 \pm 5.2 ; 5 ; 10)$ in number, $14-40(29 \pm 6.8 ; 5 ; 10)$ long by $31-50(43 \pm 5.8 ; 5 ; 10)$ wide, extending from anterior margin of proglottid to ovary, slightly overlapping anterior margins of ovary, 2 columns in dorso-ventral view, postvaginal testes present on poral side, 1 row deep, postovarian testes absent. Vas deferens in form of thin tube, coiling anterior to and at level of cirrus sac. External seminal vesicle absent. Internal seminal vesicle absent. Cirrus sac piriform, horizontally oriented in proglottid, $75-100(85 \pm 8.5 ; 4 ; 8)$ long by $38-75(54 \pm$ $12.5 ; 4 ; 9)$ wide, containing coiled cirrus. Cirrus armed. Ovary $\mathrm{H}$-shaped in dorso-ventral view, tetralobed in cross-section, 28-163 (95 $\pm 50.3 ; 4 ; 9)$ long by $65-105$ $(80 \pm 12.8 ; 4 ; 9)$ wide, lobulated, symmetrical; ovarian bridge at or slightly anterior to centre of ovary. Vagina looping between posterior lobes of ovary, then extending anteriorly from ootype region to genital pore, not crossing cirrus sac, opening anterior to cirrus sac into genital atrium; vaginal sphincter absent (Fig. 54). Genital pore lateral, $40-66 \%(54 \pm 8.2 ; 5 ; 10)$ of proglottid length from posterior end; genital pores irregularly alternating along length of strobila. Uterus saccate, extending along midline of proglottid from level anterior to ovary to level of posterior margin of cirrus sac; uterine duct not observed; uterine pore absent. Vitellaria follicular, medullary, lateral, extending entire length of proglottid, interrupted by ovary, and dorsally and ventrally by cirrus sac; vitelline follicles 9-19 (12 $\pm 2.8 ; 5$; 10) long by $8-17(12 \pm 2.7 ; 5 ; 10)$ wide; essentially 1 dorsal and 1 ventral column on each side of proglottid. Eggs not observed. One dorsal and one ventral pair of excretory vessels.

$\mathrm{T}$ y p e h o s t: Aetomylaeus niehofii (Bloch et Schneider) (Myliobatiformes: Myliobatidae), the banded eagle ray.

T y p e 1 o c a 1 i t y : Sematan $\left(01^{\circ} 48^{\prime} \mathrm{N}, 109^{\circ} 46^{\prime} \mathrm{E}\right)$, Sarawak, Malaysia.

Date of collection: May 15, 2003 (host specimen BO-180).

Site of infection: Spiral intestine.

T y p e mate ria 1 : Holotype (MZUM[P] 135); 1 paratype (SBC-C-00003); 2 paratypes (USNPC 96996); 1 paratype (LRP 3799); 3 paratypes (prepared for SEM) (KUNHM, senior author's collection).

E t y m o lo g y : This species is named in honour of Annie Lim (Fisheries Research Institute in Kuching, Sarawak), an excellent elasmobranch taxonomist and a most resourceful colleague.

\section{Remarks}

Rhoptrobothrium limae is the third species in this genus to be described from Aetomylaeus niehofii. Rhoptrobothrium limae is easily distinguished from $R$. myliobatidis based on the configuration of the remi; $R$. limae possesses a secondary areola on the remi, while a sec- ondary areola is absent in $R$. myliobatidis. In addition, $R$. limae possesses 2-4 mature proglottids, while $R$. myliobatidis possesses 2 or fewer mature proglottids. Rhoptrobothrium limae can be distinguished from $R$. chongi and $R$. gambangi based on its longer total length (2.4-5.0 vs. $1.4-1.8$ and $1-2.1 \mathrm{~mm}$, respectively). In addition, the cephalic peduncle posterior to the remi is longer in $R$. limae than in $R$. gambangi (62-325 vs. 27$52)$. Finally, $R$. limae possesses a greater total number of proglottids than $R$. chongi (9-22 vs. 5-8).

\section{Rhoptrobothrium Shipley et Hornell, 1906}

Generic diagnosis: Phyllobothriidae. Worms euapolytic. Scolex with 4 acetabula and cephalic peduncle. Acetabulum bothridiate in form, uniloculated, with anterior region loculus; anterior region loculus overlapping main loculus, with lateral pointed extensions. Cephalic peduncle bearing 4 stalked remi; each remus with terminal primary areola; secondary areola, proximal to primary areola, present or absent. Proglottids acraspedote. Testes anterior to ovary, arranged in single layer. Vas deferens coiled anteriorly, adjacent and occasionally posterior to cirrus sac. Cirrus sac piriform. Cirrus armed. Ovary H-shaped in dorso-ventral view, tetralobed in cross-section. Vagina opening into genital atrium anterior to cirrus sac. Genital pore lateral; genital pores irregularly alternating along length of strobila. Uterus median, saccate, not extending anterior to cirrus sac. Vitellaria follicular, lateral, in field anterior and posterior to ovary. Parasites of Myliobatidae. Indian Ocean, Sri Lanka; and South China Sea, Sarawak, Malaysia.

Type species: Rhoptrobothrium myliobatidis.

Other species: Rhoptrobothrium chongi; R. gambangi; $R$. limae.

\section{Remarks}

Rhoptrobothrium differs from all other tetraphyllidean genera outside of the Thysanocephalinae in its possession of remi. Among the Thysanocephalinae, Rhoptrobothrium is considered to be a valid genus, distinct from Myzocephalus and Myzophyllobothrium, at least until type material of the latter two taxa can be located, or formally replaced, and the morphologies of these latter taxa are more clearly understood. The specimens of Myzocephalus examined by Caira et al. (2001) from the type host (Aetobatus narinari) of the type species of this genus, Myzocephalus narinari Shipley et Hornell, 1906, are consistent with the description provided by Shipley and Hornell (1906) and differ in a number of respects from Rhoptrobothrium. For example, in Myzocephalus, the cephalic peduncle extensions (here termed remi) are extensive, broadly foliose and crumpled (see Fig 1A), rather than elongate, leaf-like structures as seen in all four species of Rhoptrobothrium. Based on information provided by Shipley and Hornell (1906) in its original description, Myzophyllobothrium possesses acetabula on the scolex proper that are sucker-like (see 
Fig. 1B) rather than bothridiate as in Rhoptrobothrium. The proglottid anatomy of both Myzocephalus and Myzophyllobothrium as briefly described by Shipley and Hornell (1906) is similar to that of Rhoptrobothrium. However, all three genera conspicuously differ from Thysanocephalum in that their proglottids are acraspedote, rather than craspedote, the testes are arranged in a single layer, rather than in greater than one layer, the uterus extends only to the level of the cirrus sac, rather than extending anterior to the cirrus sac, and the vitelline follicles are interrupted, rather than uninterrupted, by the ovary. These three genera are further distinguished from Thysanocephalum based on the fundamental differences in scolex structure addressed below in the discussion.

\section{DISCUSSION}

Although Myzocephalus, Myzophyllobothrium and Rhoptrobothrium were established in the same publication, and exhibit conspicuous similarities in the form of their unusual scoleces, there are a number of discrepancies in the terminology used by Shipley and Hornell (1906) in reference to the various components of the scoleces of these taxa. For example, in the generic diagnoses of Myzophyllobothrium and Rhoptrobothrium, the scolex was referred to as a "head," and considered to consist of an anterior and a posterior part, while in $M y$ zocephalus the "head" refers to the anterior part only. The anterior part was further described as possessing "four slipper-shaped bothridia each divided by a horizontal partition into two areolas" in Myzocephalus (p. 46), and as a myzorhynchus with four suckers in Myzophyllobothrium and Rhoptrobothrium (pp. 47, 58, respectively). The posterior region was described as consisting of "four most voluminous and crumpled folds like the bothridia of Anthobothrium [Van Beneden, 1850]" in Myzocephalus (p. 46), as consisting of "four bothridia, sessile, with smooth edges and a thickening (? small sucker) [sic] at the apex" in Myzophyllobothrium (p. 47), and as "four bothridia" that are "stalked and leaf-like with the terminal end cut off and forming an areola" in Rhoptrobothrium (p. 58). This terminology is further confounded in the specific descriptions of the type species of each genus. For example, with respect to Myzocephalus narinari, Shipley and Hornell noted (p. 47) that "in this worm we have a double set of bothridia, one in the head, the other forming a ruff." In the description of Myzophyllobothrium rubrum they elaborated on the form of the scolex (p. 48) and considered it to consist of a "myzorhynchus" that was "flanked by four bothria or sessile, leaf-like extensions." Shipley and Hornell (1906) described Rhoptrobothrium myliobatidis (p. 59) as possessing "a myzorhynchus" that "bears at equal distances four rather leaf-like suckers whose edges are curled inwards, and bear half-way along their edge a pair of inwardly directed projections." Of particular concern is the application of the term bothridium to disparate parts of the scoleces among different taxa. However, additional terms have also been applied to the modified posterior region of the scolex. For example, the entire posterior part of the scolex was later referred to as "metascolex" by Fuhrmann (1931) and Euzet (1994). In addition, Shipley and Hornell's use of the term myzorhynchus is inconsistent with the concept articulated by Caira et al. (1999). Clearly some consensus of terminology is needed to bring order to interpretation and discussion of these scolex features.

Terminology is most effective if it reflects homology. Homology is best determined by investigation of developmental origin, position and structure. The specimens of Rhoptrobothrium collected as part of this study did much to shed light on the actual scolex morphology of this group. The scheme we have developed is based on information generated from detailed examination of whole mounts and sections of scoleces, as well as whole mounts and sections of Myzocephalus and Thysanocephalum utilized by Caira et al. $(1999,2001)$. We have striven to be consistent with the terminology proposed by Caira et al. $(1999,2001)$, and to the greatest extent possible also with at least some of the concepts of Shipley and Hornell (1906).

The terminology and interpretation of scolex features we propose are illustrated in Fig. 2 and are described below using Rhoptrobothrium as an example. Like that of many tetraphyllideans (and members of other tetrafossate orders), the scolex of Rhoptrobothrium consists of an anterior scolex proper followed by a cephalic peduncle. In general, the scolex proper bears the primary organs of attachment, in this case, four acetabula that are bothridiate in form. The scolex proper was referred to as a myzorhynchus by Shipley and Hornell (1906). The term myzorhynchus, however, is now more commonly applied to the apical modification of the scolex proper seen in such tetraphyllidean genera as Echeneibothrium van Beneden, 1850 (e.g., see Caira et al. 1999). Unlike many tetraphyllideans, however, Rhoptrobothrium possesses unique complex extensions of the cephalic peduncle, here termed remi (remus, L., oar). The four remi of Rhoptrobothrium are considered to be extensions of the cephalic peduncle, rather than components of the scolex proper, because they differ in structure from acetabula; not only do they lack the membrane-bound organized musculature throughout much of their length that is characteristic of acetabula (see Caira et al. 1999) (see Figs. 70, 71), but their basal musculature is continuous with that of the cephalic peduncle (Fig. 69). The terminology for the subdivisions of the remi has been adopted from Shipley and Hornell (1906), who referred to these structures as areolae (areola, L., diminutive of area, open space). The distal (terminal) areola is referred to as the primary areola; if a second, subterminal areola is present it is referred to as the secondary areola. Curiously, histological work suggests that the configuration of the musculature of the primary 


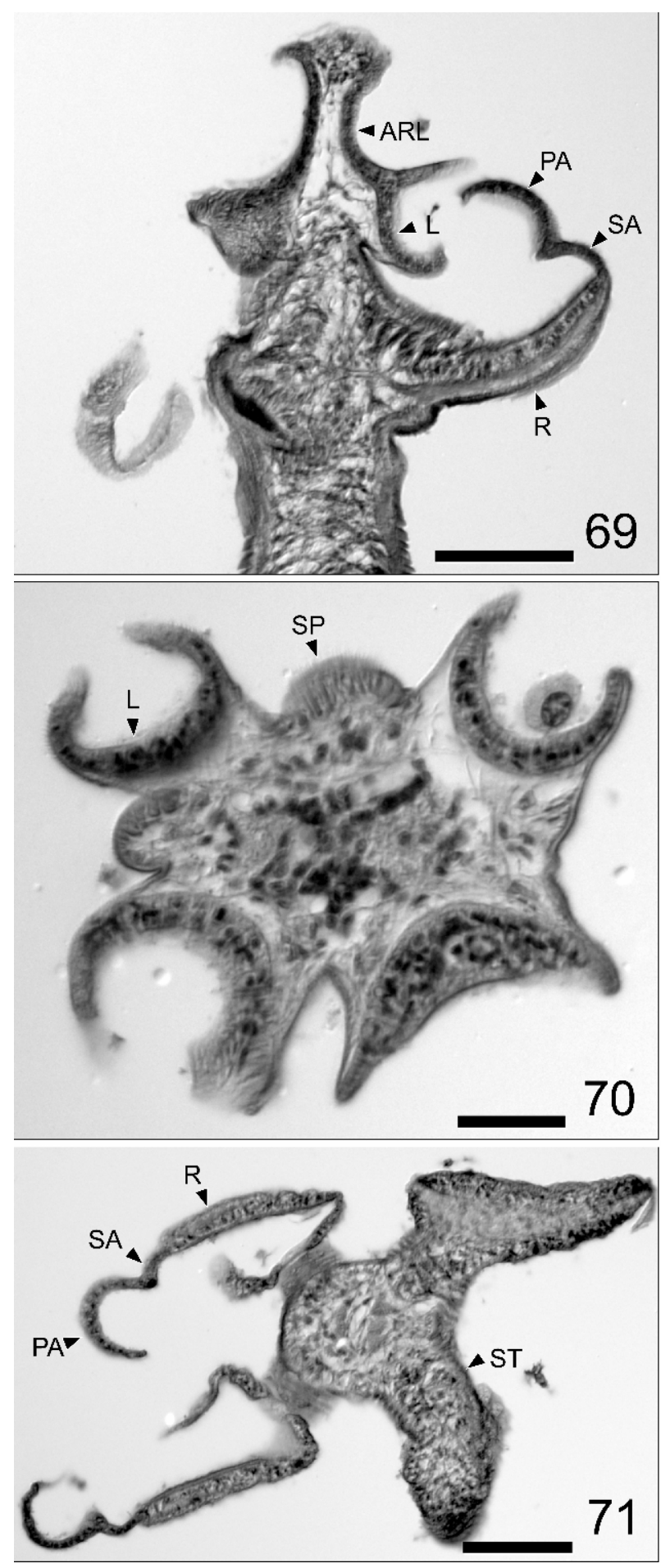

Figs. 69-71. Histological sections of the scolex of Rhoptrobothrium sp. Fig. 69. Longitudinal section through the scolex. Fig. 70. Cross-section through the scolex proper. Fig. 71. Cross-section through the remi at the level of the stalks. Abbreviations: ARL - anterior region loculus; $\mathrm{L}$ - loculus; PA primary areola; R - remus; SA - secondary areola; SP-scolex proper; ST - stalk. Scale bars: Figs. $69,71=50 \mu \mathrm{m}$; Fig. $70=$ $20 \mu \mathrm{m}$. areola, and possibly that of the secondary areola, is very similar to that of the acetabula (see Figs. 69, 71). Given its position, however, we do not consider the primary areola to be homologous to the acetabula of the scolex proper. This interpretation is similar to that of Caira et al. (2001) for Myzocephalus, who revealed that the posterior part of the scolex (i.e., the "metascolex") in $M y$ zocephalus was cephalic peduncular, and not acetabular, in origin, and was clearly tetrapartite in nature. These peduncular extensions also lacked the organized, membrane-bound musculature characteristic of acetabula (compare figs. 87 and 86 in Caira et al. [2001] to Figs. 69 and 71, respectively), and, based on the terminology introduced here for Rhoptrobothrium, should be termed remi. To our knowledge, subdivisions of the remi (i.e., areolae) have not been observed in Myzocephalus. While Euzet's (1994) decision to consider Mixophyllobothrium a synonym of Myzocephalus is not questioned here, additional information on the scolex morphology of the type and only species, Mixophyllobothrium okamuri Shinde et Chincholikar, 1981, is necessary to confirm the presence of remi and the lack of areolae in this species.

The detailed morphology of the scolex of Myzophyllobothrium has never been investigated. In fact, given the paucity of information available for this genus, much uncertainty exists about its taxonomic status. To our knowledge, it has been collected on only one occasion since its original description in 1906. Southwell (1925) reported having found two specimens and several fragments in Aetobatus narinari from the Ceylon Pearl Banks in 1909. He also mentioned that, through the kindness of Sir Arthur Shipley, he was able to compare his specimens to cotypes of Myzophyllobothrium rubrum. As a result of the museum work conducted for the present study, we were fortunate to locate three slides labeled "Myzophyllobothrium rubrum co-types Aetobatis [sic] narinari Shipley 8.8.23" which appear to have come from Southwell's collection. These specimens have now been deposited at the BMNH (Nos. 2006.7.14.1-3). One slide bears a scolex mounted in apical view and a strobilar fragment consisting of very immature proglottids; the second slide bears several strobilar fragments and detached mature proglottids; the third slide bears a long strobilar fragment consisting primarily of mature proglottids. Based on the nature of the material and the date on the slides, it seems unlikely that these slides actually represent type material. However, the label data, written in Southwell's hand, suggest that at least Southwell, having seen type material of Myzophyllobothrium rubrum, considered them to represent this species. Unfortunately, the orientation of the scolex obscures the details of its components making homology determinations, beyond those that can be drawn from the original illustrations, impossible to judge at this time. 
Terminology for the elaboration of the region of the scolex posterior to the scolex proper has been applied in tetraphyllideans other than Rhoptrobothrium, Myzocephalus and Myzophyllobothrium. A metascolex, as defined by Fuhrmann (1931), is an elaboration of the posterior part of the cephalic peduncle ("Kopfstiel," according to Fuhrmann), and thus differs fundamentally from a pseudoscolex, which is essentially an elaboration/modification of the anterior part of the strobila. Given this distinction, the term "metascolex" is very appropriately applied to the remi of Rhoptrobothrium, Myzocephalus, and, based on the illustration provided by Shipley and Hornell (1906), Myzophyllobothrium. Species of Thysanocephalum have been described as possessing a metascolex, and Disculiceps Joyeux et Baer, 1936 as possessing an elaborated collar-like region (e.g., see Pintner 1928, Euzet 1994), resembling a metascolex. It appears that the "metascolex" of Thysanocephalum differs fundamentally in structure from the remi of Rhoptrobothrium and the two should not be considered homologous. Caira et al. (1999) showed that the "metascolex" of Thysanocephalum is a highly folded continuation of the acetabular loculus rather than an elaboration of the cephalic peduncle. This interpretation calls into question the current grouping of Thysanocephalum, and Rhoptrobothrium, Myzophyllobothrium and Myzocephalus in the subfamily Thysanocephalinae (e.g., see Euzet 1994). In addition, Thysanocephalum differs conspicuously from the latter three genera in many features of proglottid anatomy including arrangement of testes, anterior extent of the uterus, distribution of vitelline follicles and vaginal course relative to the cirrus sac. Since Thysanocephalum is the type of the Thysanocephalinae, it is the latter three genera that are dubious members of this subfamily. However, because the phylogenetic relationships among tetraphyllidean taxa is currently in flux and is highly controversial (e.g., see Caira et al. 1999, 2001, Olson and Caira 1999, Ol- son et al. 1999, 2001) we will refrain from transferring these genera to a more appropriate higher taxon at this time.

The homologies of the metascolex of Disculiceps and remi is more difficult to resolve. In Disculiceps the posterior part of the scolex was described by Euzet (1994) as a "complex, frilled velum, probably in four parts (bothridia?)" (p. 164). Caira et al. (1999) investigated the scolex morphology of Disculiceps in more detail through histological sections and determined that the "frilled" part originated from the cephalic peduncle and was not quadripartite in structure and should thus not be considered to consist of remi. Although Disculiceps could be considered to possess a "metascolex," it could be argued that its cephalic peduncular elaboration appears to be unique among tetraphyllideans (see Pintner 1928).

Also unclear at this time is the relationship between the metascolex of tetraphyllideans such as Rhoptrobothrium, and those described for some proteocephalidean taxa (e.g., see Rego 1994).

Acknowledgements. We are very grateful to Mr. Albert Gambang and Ms. Annie Lim of the Fisheries Research Institute in Kuching for facilitating collections in Sarawak. We are also grateful to Gordon Yearsley, CSIRO, Tasmania, for assisting with collections of hosts in 2002. Captain Hamri bin Hji-Kating and his son Sebli bin Hamri are thanked for collecting the specimens of Aetomylaeus in 2003. The senior author thanks Dr. Bruce Cutler for his expert technical assistance with the use of the SEM at the University of Kansas. These collections were conducted under collecting permit No. UPE:40/200/19SJ.924 from the Economic Planning Unit in Kuala Lumpur and research agreement No. SBC-RA-0050JNC from the Sarawak Biodiversity Center in Kuching. This work was supported with funds from an NSF BS\&I grant No. DEB 0103640, a Lerner-Gray post-doctoral grant to KJ and in part with funds from an NSF PEET grant No. DEB 011882.

\section{REFERENCES}

CAIRA J.N., JENSEN K., HEALY C.J. 1999: On the phylogenetic relationships among tetraphyllidean, lecanicephalidean and diphyllidean tapeworm genera. Syst. Parasitol. 42: 77-151.

CAIRA J.N., JENSEN K., HEALY C.J. 2001: Interrelationships among tetraphyllidean and lecanicephalidean cestodes. In: D.T.J. Littlewood and R.A. Bray (Eds.), Interrelationships of the Platyhelminthes. Taylor \& Francis, London, pp. 135-158.

EUZET L. 1994: Order Tetraphyllidea Carus, 1963. In: L.F. Khalil, A. Jones and R.A. Bray (Eds.), Keys to the Cestode Parasites of Vertebrates. CAB International, Wallingford, England, pp. 149-194.

FUHRMANN O. 1931: Dritte Klasse des Cladus Plathelminthes: Cestoidea. In: W. Kükenthal and T. Krumbach (Eds.), Handbuch der Zoologie (1928-1933). Walter de Gruyter \& Co., Berlin, pp. 141-416.
OLSON P.D., CAIRA J.N. 1999: Evolution of the major lineages of tapeworms (Platyhelminthes: Cestoidea) inferred from $18 \mathrm{~S}$ ribosomal DNA and elongation factor-1 $\alpha$. J. Parasitol. 85: 1134-1159.

OLSON P.D., LITTLEWOOD D.T.J., BRAY R.A., MARIAUX J. 2001: Interrelationships and evolution of the tapeworms (Platyhelminthes: Cestoda). Mol. Phylog. Evol. 19: 443-467.

OLSON P.D., RUHNKE T.R., SANNEY J., HUDSON T. 1999: Evidence for host-specific clades of tetraphyllidean tapeworms (Platyhelminthes: Eucestoda) revealed by analysis of 18S ssrDNA. Int. J. Parasitol. 29: 1465-1476.

PINTNER T. 1928: Die sogenannte Gambothriidae, Linton, 1899. Zool. Jahrb., Abt. Anat. Ontog. Tiere 50: 55-116.

REGO A.A. 1994: Order Proteocephalidea Mola, 1928. In: L.F. Khalil, A. Jones and R.A. Bray (Eds.), Keys to the Cestode Parasites of Vertebrates. CAB International, Wallingford, England, pp. 257-293. 
SCHMIDT G.D. 1986: Handbook of Tapeworms Identification. CRC Press, Boca Raton, Florida, 675 pp.

SHINDE G.B., CHINCHOLIKAR L.N. 1980: Mixophyllobothrium okamuri gen. nov. sp. nov. (Cestoda: Tetraphyllida) from Trygon sephen at Ratnagiri, India. Riv. Parassitol. 41: 413-417.

SHIPLEY A.E., HORNELL J. 1906: Report on the cestode and nematode parasites from the marine fishes of Ceylon. Report to the Government of Ceylon on the Pearl Oyster Fisheries of the Gulf of Manaar (Herdman), Part 5: 43-96.

Received 28 February 2005
SOUTHWELL T. 1925: A monograph on the Tetraphyllidea with notes on related cestodes. Mem. Liverpool School Trop. Med. (New Series) 2: 1-368.

SOUTHWELL T. 1930: Cestoda. Vol. I. In: J. Stephenson (Ed.), The Fauna of British India, Including Ceylon and Burma. Taylor and Francis, London, $391 \mathrm{pp}$.

WARDLE R.A., McLEOD J.A. 1952: The Zoology of Tapeworms. University of Minnesota Press, Minneapolis, 780 $\mathrm{pp}$.

YAMAGUTI S. 1959: Systema Helminthum. Volume II. The Cestodes of Vertebrates. Interscience Publishers, New York, $860 \mathrm{pp}$.

Accepted 2 May 2006 